\title{
Et kvalifisert utdanningsvalg for dagens ungdom: Resultater fra et innovasjons- samarbeid mellom en ungdomsskole, en videregående skole og en bedrift
}

\author{
(A qualified education choice for today's youth: Results from an \\ innovative collaboration between one lower secondary school, \\ upper secondary school and industrial company)
}

\section{Sylvi Thun, Linn Thøring \& Lisbeth Øyum}

SINTEF Digital, Norge (linn.thoring@sintef.no)

\section{Abstract}

The purpose of this article is to investigate how an innovative collaboration between one lower secondary school, upper secondary school and industrial company can contribute to a more informed educational choice (vocational vs. programme for specialisation in general studies) among today's youths. Eight lower secondary school students, five upper secondary school students, one employee in the participating industrial company, one teacher from lower secondary school, one from upper secondary school together with the section leader for vocational education programme (upper secondary school) have been interviewed. Thematic analysis has been used to analyse the data. The theoretical perspectives undertaken are self-determination theory and social-cognitive theory. Findings highlight that the study's innovative collaboration gives youths an essential insight into the future school- and work practices. During the collaboration, the youths learn about the competence needs for future work life, and gain knowledge about their own learning potentials. Practical experience, new ways of collaboration, work centred communication, engaging and challenging training situations, experience of meaning, together with responsibility taking for own and other's learning contribute to a more qualified education choice. We find that the pupils in lower secondary school experienced this innovative collaborative practice to produce more autonomous than controlled motivation, and more positive outcomes in terms of both behavioural, cognitive and affective dimensions of learning, at school.

Keywords: autonomous motivation, education, innovative collaboration, self-efficacy, thematic analysis, choice of education, vocational education and training 


\section{Innledning}

Ungdommers utdanningsvalg og fullføring av videregående opplæring er et tema som har stor samfunnsmessig oppmerksomhet og betydning. Etter ti år $\mathrm{i}$ det norske grunnskolesystemet har alle norske ungdommer lovfestet rett til videregående opplæring. Her kan elevene velge å enten ta studieforberedende videregående opplæring, som kvalifiserer dem til å søke opptak til høyere utdanning, eller yrkesfaglig utdanning. Yrkesfaglig utdanningsretning i norsk videregående skole er organisert som en kombinasjon av opplæring i skole og opplæring i bedrift. Hvordan utdanningsløpet er lagt opp varierer etter hvilken utdanning man tar, men det mest vanlige utdanningsløpet er toårig skolegang, Videregående 1 (VG1) og Videregående 2 (VG2), og dernest to år læretid i en bedrift. I læretiden får lærlingen en kollega som instruktør, som gir veiledning i utføring av de oppgavene som inngår i læreplanen for det aktuelle faget. Det første året i bedriften regnes som opplæring, mens i det andre året bidrar eleven mer aktivt $i$ produktivt, verdiskapende arbeid. De to årene avsluttes med eksamen (i form av en fagprøve) som fagarbeider ${ }^{1}$.

Både i arbeids- og samfunnslivet har det derimot i flere år vært uttrykt stor bekymring over at mange ungdommer ikke greier å gjennomføre det videregående utdanningsløpet, og da særlig innen yrkesfaglig utdanningsretning. Tall fra Statistisk Sentralbyrå 2 i juni 2019 viser at 75,3 prosent av elevene eller lærlingene fullførte med studie- eller yrkeskompetanse i løpet av 5 år. For studieforberedende utdanningsprogram er andelen 88 prosent, mens den er 62 prosent for yrkesfaglig utdanningsprogram. Disse tallene har vært helt stabile, målt i prosentpoeng endring siden 2012. I en norsk offentlig utredning om "Fremtidige kompetansebehov I - Kunnskapsgrunnlaget" argumenteres det for at dagens gjennomføringsgrad fortsatt er for lav (NOU 2018:2). De samfunnsmessige- og individuelle kostnadene ved å ikke delta i samfunnet gjennom arbeidslivstilknytning er store. Både arbeidslivet og velferdssamfunnet har behov for at dagens ungdom opplever mestring og motivasjon i sin skolegang slik at de kan bli de fremtidige arbeidstakerne Norge har behov for, for å få vekst i konkurranseutsatte næringer og opprettholdelse av god tjenesteproduksjon i velferdstilbudet. Årsakene til frafall er mange og sammensatte. Noen av de identifiserte risikofaktorene er geografisk nærhet til studiestedet, regionale arbeidsmarkedsforhold, kjønn, foreldres utdanningsnivå, og grunnskolepoeng (Falch et al., 2010). Bunting og Moshuus (2017) argumenterer derimot for at mye av forskningen om skoleavbrudd i videregående opplæring ser på individuelle eller strukturelle risikofaktorer, og at vi heller må se på skoleavbrudd som noe som skjer i møtet mellom den individuelle ungdommen og systemet. I sin intervjustudie av ungdommer som får bistand fra $\mathrm{NAV}^{3}$ og som ikke har ferdigstilt sitt videregående utdanningsløp, blir enkelthendelser som for eksempel manglende lærlingekontrakt eller ikke-bestått i ett fag, trukket frem som årsak for sitt skoleavbrudd. I sin analyse av 
avbruddsprosessene finner forskerne derfor, at det er sosialt medierte prosesser også utenfor skolen som må vektlegges for å forstå skoleavbrudd (Bunting \& Moshuus, 2017).

Formålet med denne artikkelen er å undersøke om et innovasjonsrettet samarbeid mellom grunnskolen, videregående yrkesfaglig utdanning og arbeidslivet kan bidra til at ungdomsskoleelever tar et bedre og mer kvalifisert utdanningsvalg. I tillegg ønsker vi å se om et slikt samarbeid har en nytteverdi for alle de involverte partene. Vi har derfor følgende forskningsspørsmål: Hvordan kan et samarbeid mellom ungdomsskole, videregående skole og industribedrift bidra til at ungdomsskoleelever tar et mer kvalifisert utdanningsvalg og skape nytteverdi for alle involverte parter?

Messmann og Mulder (2011) argumenterer for at det er utfordrende for ungdom å foreta et utdanningsvalg blant annet fordi det er vanskelig å finne treningsarenaer og fordi dagens jobbprofiler krever andre kompetanser enn man tradisjonelt har kjennskap til. Derfor, i aksjonsforskningsprosjektet som danner utgangspunkt for denne artikkelen, undersøker vi om innovative former for samarbeid mellom ungdomsskole, videregående skole og industribedrift kan gi ungdom et bedre grunnlag for å foreta et aktivt utdanningsvalg. En forventet nytteverdi er at ungdomsskoleelever som får innsikt i både hvordan skolehverdagen på yrkesfaglig utdanning og arbeidsprosessene i en industribedrift ser ut, lettere kan ta et kvalifisert utdanningsvalg. Dette kan bidra til økt motivasjon for å gjennomføre videregående skole. Forventet nytteverdi for skolene er økt kunnskap om hvordan slike samarbeidsprosjekter bør organiseres. Forventet nytteverdi for bedriften er å kunne påvirke innholdet i undervisningen slik at det samsvarer med deres behov, samt tettere kontakt med mulige fremtidige lærlinger og etter hvert fagarbeidere.

Kompetansenivået i norsk arbeidsliv utgjør en viktig faktor i det som refereres til som "den norske modellen" (Levin et al., 2012; Ravn \& Øyum, 2018). Vi ser allerede starten på et arbeidsliv preget av helt nye digitale teknologier, og vi vet at behovet blir stort for både organisatoriske og teknologiske innovasjoner for å levere produkter og tjenester hvor kunden og brukeren er tettere på verdikjedene. Den største norske arbeidsgiverforeningen, Norsk Hovedorganisasjon (NHO), gjennomfører hvert år en undersøkelse (Kompetansebarometeret) blant sine medlemsbedrifter for å få kunnskap om deres behov for kompetanse framover. Når 61 prosent av utvalget av bedrifter i Kompetansebarometer 20194 rapporterer at de har et udekket kompetansebehov, særlig etter fagarbeidere innen håndverksfag, er dette bekymringsfullt. Bedriftene rapporterer videre at behovet for ytterligere kompetanseheving hos de ansatte er stort også etter ferdig formell utdanning, og at flertallet av bedriftene vil gjennomføre denne kompetansehevingen i form av interne, bedriftsrettede tiltak. Med utgangspunkt i dette vil opplevelsen av mestring i skolehverdagen gi et godt utgangspunkt for motivasjon til å delta i kontinuerlig læring som arbeidstaker. 
Antall ungdomsskoleelever som velger yrkesfag i dag er lavere enn morgendagens behov. I 2013 gjennomførte Velferdsforskningsinstituttet NOVA er forsøk med valgfaget arbeidslivsfag på ungdomstrinnet (Bakken et al., 2013). De fant blant annet at, "... faget representerer noe annet enn det som ellers tilbys elevene $i$ skolen, det gir elever pusterom fra andre fag og for mange er arbeidslivsfaget et sted hoor de får mestringsopplevelser de ellers ikke får så mange av i skolen" (Bakken et al., 2013, s. 161). Forsøket viste at flertallet av elevene opplevde trivsel og at faget var nyttig, at faget representerte en arbeidsform som ga tid og anledning til dialog mellom lærer og elev, og at praktiske oppgaver forsterket elevenes tilfredshet. Rapporten understreker ungdomsskolens behov for å kunne tilby reell arbeidspraksis $i$ et tettere samarbeid med lokale virksomheter. Videre anbefales det å få et tettere samarbeid mellom ungdomstrinnet og videregående skoler, slik at ungdomsskoleelever blir bedre kjent med de yrkesfaglige programmene og arbeidslivet. Tidligere forskning har vist at det har stor betydning for elevenes valg av yrke at de får muligheten til noe praktisk utdanning, og at de opplever et samarbeid mellom skole og arbeidsliv gjennom arbeidspraksis som en del av den skolebaserte utdanningen (Aakernes, 2018). Men, i Bakken med kolleger (2012) sin rapport om læreres og elevers erfaringer med arbeidslivsfag, ble det rapportert at én av tre elever trodde arbeidslivsfaget skulle være bedre enn det viste seg å være. For noen av disse ungdommene handlet skuffelsen om at undervisningen foregikk for lite "ute i det virkelige livet". Mange elever skulle ønske at faget ga dem flere praktiske erfaringer utenfor skolesettingen, og de etterspør mer bruk av utplassering, bedriftsbesøk og jobbing utenfor skolen. For andre knyttes skuffelsen til at faget ikke har vært praktisk nok. Studien dokumenterte at de ungdommene som jobbet mye praktisk, likte faget en god del bedre enn de som hadde jobbet mindre praktisk, og de førstnevnte er spesielt godt fornøyd med arbeidsmåten i faget (Bakken et al., 2012).

Høsten 2020 startet implementeringen av nye læreplaner i yrkesfag. De nye læreplanene vektlegger bærekraftig utvikling og det å kunne bruke og forstå ny teknologi. I tillegg er det lagt vekt på at elevene skal få muligheten til å spesialisere seg tidligere enn i dag, og det elevene lærer på skolen, skal være relevant for arbeidslivet. ${ }^{5}$ For å oppnå dette, må skolene i større grad enn før samarbeide med næringslivet, og det foreligger et behov for å undersøke om det er mulig å tenke mer innovativt rundt bruken av arbeidslivsfag i skolen. Denne artikkelen kan være et bidrag til å skissere ett mulig design på et slikt samarbeid.

\section{Teoretisk rammeverk}

\section{Selvbestemmelsesteorien}

Selvbestemmelsesteorien (Self-determination theory) er en empirisk basert teori som omhandler motivasjon, utvikling og helse/velvære (well-being) (Deci \& 
Ryan, 1985, 2008). Teorien har blitt benyttet innen ulike domener, hvorav utdanning er et av dem (Deci et al., 1991). I utdanningskonteksten har denne teorien primært blitt brukt til å promotere elever og studenters interesse til å lære, verdsette utdannelse, og fremme troen på egne evner, kapasitet og tillagte egenskaper. For å øke slike verdifulle utfall er det ifølge teorien motivasjon, internalisering av verdier og hvordan en regulerer ulike prosesser som har betydning. Motivasjon gir oss energi til å handle (Deci \& Ryan, 2000; Olafsen, 2018).

Det tradisjonelle synet på og en noe forenklet måte å definere motivasjon på er indre motivasjon (interesse og glede ved å engasjere seg $i$ en oppgave), versus ytre motivasjon (handling som resultat av belønning og straff). Selvbestemmelsesteorien har et mer differensiert syn på motivasjon enn det tradisjonelle. Teorien viser hvordan tre ulike motivasjonstyper, autonom motivasjon, kontrollert motivasjon og amotivasjon, kan utvikles og implikasjonene av disse (Olafson, 2018). Disse tre typene predikerer god utførelse, relasjonelle- og velværerelaterte utfall. Det er ikke mengdegrad eller styrke som teller, men innhold og kvalitet.

Det foreligger en lang rekke med empiriske studier som har funnet støtte for at mennesker drives av ulike typer motivasjon. Autonom motivasjon omhandler handlinger og atferd som kommer som et resultat av en følelse av egen vilje og opplevelse av å ha tatt et valg (Gagné \& Deci, 2005). Kontrollert motivasjon er koblet til handlinger og atferd som er drevet av en følelse av press til å måtte utføre en handling. Både autonom og kontrollert motivasjon er intensjonelle, i motsetning til amotivasjon, som er fullstendig mangel på motivasjon.

I tillegg adresserer teorien hvordan egenskaper ved den sosiale konteksten er med på å påvirke disse motivasjonstypene, gjennom å forsterke/undergrave eller tilfredsstille/ hindre grunnleggende psykologiske behov som autonomi, tilhørighet (relatedness) og kompetanse. For å utvikle oss som mennesker, må våre psykologiske behov tilfredsstilles. Behovet for autonomi henviser til handling gjennomført på bakgrunn av egne valg og med en følelse av egen vilje (deCharms, 1968; Deci et al., 1992). Behovet for tilhørighet refererer til det å føle at andre bryr seg om og respekterer oss, at vi bryr oss om og respekterer andre, samt føle tilknytning til andre (Baumeister \& Leary, 1995; Deci et al., 1992). Behovet for kompetanse uttrykker vårt behov for å bruke og utvikle vår kompetanse, samt oppleve at en mestrer omgivelsene (Deci et al., 1992; White, 1959). Disse grunnleggende psykologiske behovene fasiliteter motivasjon.

En sentral hypotese i selvbestemmelsesteorien er at elever som er regulert av autonom motivasjon vil oppleve positive utfall (både atferdsmessige, kognitive og affektive) på skolen. Forskning har vist at autonom motivasjon predikerer skolenærvær og vedholdenhet, gjennomføringsgrad, skoletilfredshet, prestasjoner og måloppnåelse (Guay et al., 2008). Motivasjonstypene påvirker ulike utfall. For eksempel, en elev som opplever glede og entusiasme når en regner matematikk, trenger ikke oppleve samme glede og entusiasme ved lesing. Elever som skåret høyt på autonom motivasjon rapporterte flere positive emosjoner i 
klasserommet, at de er mer fornøyde med akademisk arbeid, og bedre tilfreds med skolen enn de som skåret lavt på denne typen motivasjon (Vallerand et al., 1989, omtalt i Vallerand et al., 1997). Studier gjennomført med selvbestemmelsesteorien som et teoretisk rammeverk, viser at jo mer press elever føler, jo dårligere presterer de. Forhold i den sosiale konteksten er altså med på å påvirke type motivasjon (Deci et al., 1992), for eksempel vil både foreldre og lærere være signifikante påvirkere ved utvikling av elevers autonome motivasjon. En lærer som involverer seg, og har en støttende og autonom lærerstil vil bidra til en struktur hvor en kan få bedre internalisering av autonome læringsaktiviteter i utdanningskontekster (Deci et al., 1992; Guay et al., 2008). En annen teori som også vektlegger motivasjon og læring er sosial-kognitiv teori.

\section{Sosial-kognitiv teori og mestringsforventning}

Essensen i sosial-kognitiv teori er læring som en prosess som skjer i interaksjon mellom atferd, personlige egenskaper og omgivelser. Sosial-kognitiv teori er en utvidelse av Banduras sosiale læringsteori. For at læring skal oppstå må en være motivert for å lære, og ifølge sosial-kognitiv teori skjer læring gjennom egne erfaringer, oppfattelser, tanker og observasjoner (Bandura, 1986, 2012). Observasjon er et vidt begrep og inkluderer både demonstrasjoner, skriftlig og/eller muntlig instruksjon og observasjon av andres atferds sammenheng med belønninger/konsekvenser.

Ifølge teorien er det et gjensidig forhold, en triadisk gjensidighet, mellom en persons kognitive egenskaper (tanker, forestillinger og emosjoner), personens miljø og personens atferd eller handlinger (Bandura, 1986, 2012). At det er en gjensidighet mellom relasjonene innebærer at de påvirker hverandre og at eleven for eksempel ikke styres kun av indre drivkrefter eller kun av miljøet, men påvirkes av begge deler når det kommer til læring. Hvilken av de tre relasjonene som dominerer, er situasjonsavhengig. For eksempel, ved en frivillig aktivitet vil elevens valg og innsats styres sterkere av det indre enn av læreren (miljøet). Ved en obligatorisk oppgave er det mer sannsynlig at innsatsen påvirkes mest av læreren (Skaalvik \& Skaalvik, 2013).

I sosial-kognitiv teori står selvregulert læring sterkt. Denne læringsprosessen omhandler egen målsetting, det å være i stand til å vurdere hva som skal til for å nå målet, vurdere egen kompetanse og hva man eventuelt trenger for å lære, planlegge og gjennomføre en oppgave, vurdere og reflektere over prosessen, samt vurdere om resultatet ble som ønsket eller om man må giøre noe annerledes (Skaalvik \& Skaalvik, 2013). Tanken er at eleven kan lære å styre og regulere sin egen læring, og dermed ta ansvar for deler av læringsprosessen. Dette krever det Bandura kaller human agency - å være agent i eget liv, som handler om individets tro på at en har evne til å ta kontroll over eget liv. Det innebærer å handle intensjonalt, altså at man ikke handler tilfeldig, men har et mål med det man gjør (Bandura, 2005). Det er ikke gitt at den som handler ser konsekvensene av 
handlingen, og det å utvikle seg til å fungere godt som agent i eget liv krever en rekke ferdigheter. Den mest sentrale ferdigheten er mestringstro (personlig forventning om mestring), også kalt mestringsforventning i norsk litteratur (Bandura, 2005). Dette handler om elevens tro på hvor godt en er i stand til å planlegge og gjøre det som skal til for å mestre oppgaven en står overfor. I en læringssituasjon vil det bety at elevenes tanker og hans tro på sin egen mestring vil være avgjørende for hva han eller hun kan tilegne seg av kunnskap. Tidligere forskning har vist at mestringsforventning påvirker læring, motivasjon, selv-regulering og måloppnåelse (Multon et al., 1991).

Mestringsforventning kan påvirke utdanningskonteksten på flere måter, og det finnes flere typer for mestringsforventning (Bandura, 1977; Schunk \& DiBenedetto, 2016). De mest sentrale i denne konteksten er mestringsforventning relatert til læring, utførelse og selvregulert læring (Bandura, 1977; Schunk \& DiBenedetto, 2016), forventninger om det som må til for å løse en bestemt oppgave og om resultatet av det en har gjort.

Tidligere forskning har vist at elever med høy mestringsforventning sammenlignet med de elevene som skårer lavt på mestringsforventning, har en tendens til å jobbe hardere, vise mer utholdenhet, vise større interesse for læring samt nå høyere kunnskapsnivå (Bandura, 1977; Moos \& Azevedo, 2009). Mestringsforventning har også vist seg å predikere akademiske prestasjoner (Multon et al., 1991; Pajares, 2006). En elev som ikke forventer mestring kan komme til å trekke seg unna, unngå situasjonen og raskere gi opp, mens en elev som forventer mestring vil ha mer pågangsmot til å prøve å håndtere situasjonen på en god måte (Bandura, 1977, 2005). Elevens opplevelser i læringssituasjoner vil påvirke mestringsforventingen. Tidligere erfaring med å mislykkes med en oppgave, vil svekke forventningen om å mestre lignende oppgaver i fremtiden. Erfaringer med å lykkes vil derimot styrke mestringsforventningen, og erfaringer med å mislykkes senere vil da påvirke forventningen om mestring i mindre grad. For vanskelige oppgaver vil svekke mestringsforventningen, og oppgaver som er for enkle vil ikke gi opplevelsen av økt kompetanse. Vanskelighetsgraden må være på riktig nivå, tilpasset hver enkelt elev sine forutsetninger, slik at eleven opplever mestring etter å ha hatt en reell utfordring (Skaalvik \& Skaalvik, 2013).

\section{Kort oppsummering om og bruk av teoretisk rammeverk}

Selvbestemmelsesteorien viser hvordan grunnleggende psykologiske behov som autonomi, tilhørighet og kompetanse må dekkes for at man skal utvikle seg som menneske, og at en tilfredsstillelse av disse behovene bidrar til utvikling av autonom motivasjon, som gir positive utfall hos skoleelever. I likhet med selvbestemmelsesteorien legger også sosial-kognitiv læringsteori stor vekt på den sosiale konteksten i undervisningen. I tillegg til indre faktorer, vil ytre faktorer (som læreren og klassemiljøet) påvirke læringsprosessen. Elevens tidligere opplevelser i læringssituasjoner påvirker forventningen om mestring. En elev som har 
mestringsforventning, vil kunne utvikle seg til å bli agent i eget liv og styre og regulere sin egen læring. Dette teoretiske rammeverket gir oss verktøy til å drøfte hvordan deltakelsen i prosjektet oppleves for elevene, og om arbeidsoppgavene og organiseringen er lagt opp på en måte som gir elevene gode opplevelser knyttet til læring og motiverer dem til å ta yrkesfaglig utdanning og bli fagarbeidere.

\section{Kompetansebehov for fremtidens fagarbeider}

Kunnskaps- og kompetansebehov er i stor grad definert av hva som oppleves relevant og nødvendig for fremtidens arbeids- og samfunnsliv. For grunnskole og videregående skole skal Fagfornyelsen ${ }^{6}$, som trådte i kraft i år, bidra til en enda større arbeids- og samfunnsrelevans i utdanningen. For høyere utdanning vil det i 2021 ferdigstilles en Stortingsmelding om Arbeidslivsrelevans med målsetting om bedre og mer gjensidig samarbeid mellom universiteter og høyskoler og arbeidslivet om samfunnets kunnskapsbehov, utvikling av høyere utdanning og studentenes læring?.

Kravene til innholdet i fagarbeiderkompetansen, som etterspørres i industrielle virksomheter er også i radikal endring, ikke minst som følge av nye digitale teknologier for å møte en stadig voksende global konkurransesituasjon. Det Europeiske læringsnettverket "Key Competence Network on School Education" $\left(\mathrm{KeyCoNet}^{8}\right)$ har identifisert et sett av nøkkelkompetanser som arbeidslivet trenger, blant annet digital kompetanse, lære og lære, og evne til å ta initiativ og utøve entreprenørskap. Tilsvarende har prosjektet "Assessment and Teaching of 21st Century Skills" (ATC2015') identifisert fire hovedgrupper av kompetansekrav: 1) ways of thinking, 2) ways of working, 3) tools for working and 4) living in the world. Stortingsmelding NOU 2014:7 om elevenes læring i fremtidens skole konkluderer i samme retning, men de gjør et skille på såkalt fagspesifikk- og generisk kompetanse. I en industriell setting vil for eksempel digital kompetanse, kunnskap innen matematikk og naturvitenskap og språkferdigheter være fagspesifikke kompetanser, mens evne til å lære, kritisk problemløsning, samarbeidskompetanse og kulturell kompetanse vil være generiske kompetanser.

Ifølge Solem med kolleger (2016) som har intervjuet ansatte i industri og byggog anleggsnæringen om fremtidens kompetansebehov, vil den samlede kompetansen til en god fagarbeider bestå av slike både generiske og fagspesifikke kompetanser. Disse kompetansene består av ulike ferdigheter og egenskaper som til sammen skaper den moderne fagarbeiderrollen for eksempel: Gode ferdigheter i det bransjespesifikke basisfaget, kommunikasjonsferdigheter, ansvarskompetanse og innovasjonsevne (Solem et al., 2016).

Med basisfag menes den yrkesfaglige utdanningen fra videregående skole og læretiden. Med kommunikasjonsferdigheter menes generell ferdighet i kommunikasjon, som for eksempel evne til å uttrykke seg, stille spørsmål, lytte aktivt, gi konstruktive tilbakemeldinger, løse problemer og konflikter. 
Ansvarskompetanse kan beskrives som at man evner å medvirke i viktige beslutningsprosesser, tar ansvar for egen arbeidsplass, egen arbeidsinnsats og andres arbeidsinnsats, og arbeider selvstendig uavhengig om det er en leder til stede. Innovasjonsevne (også kalt innovasjonsaktiv) handler om å bruke egne erfaringer for å omstille, videreutvikle eller utvikle nye arbeidsprosesser, produkter, markeder eller egen organisasjon. I casebeskrivelsen i neste kapittel presenteres hvordan disse kompetansene dannet utgangspunktet for den oppgavebeskrivelsen ungdomsskoleelevene skulle jobbe etter i sitt samarbeid med videregående skole og bedrift.

\section{Forskningsmetode og casebeskrivelse}

\section{Innovasjonsprosjektet "Fra fjortis til fagarbeider"}

"Fra fjortis til fagarbeider" er et av flere delprosjekter i det Forskningsrådsfinansierte kompetanseprosjektet "SKILLS - Fremtidens fagarbeider"10, hvor målet var å identifisere hvilken kompetanse fremtidens industrielle fagarbeidere trenger, og hvordan skole og bedrift kan samarbeide på nye måter for å møte disse kravene. I "Fra fjortis til fagarbeider" ønsket vi å finne ut hvordan ungdomsskole, videregående skole og bedrift kunne samarbeide om innholdet i ungdomsskoleelevenes valgfag arbeidslivsfag. Målet med innovasjonsprosjektet var å øke ungdomsskoleelevenes innsikt i hvordan det er å gå yrkesfag og oppleve nærhet til arbeidslivet for å dermed kunne ta et kvalifisert utdanningsvalg. I tillegg til å gi innsikt i hva som kreves for å få til et innovativt samarbeid, ble prosjektet designet slik at et delfokus var å se om et slikt samarbeid også ville skape noen form for nytte for alle involverte parter. Prosjektet har blitt utprøvd to ulike steder. Denne artikkelen baserer seg på funn fra ett av de to stedene hvor denne samarbeidsformen nå er ferdig gjennomført. 16 av 20 de ungdoms-skoleelevene valgte å delta. Oppgaven som ungdomsskoleelevene skulle løse var å bygge en flåte ut fra spesifikasjoner om størrelse, antall passasjerer, materialbruk (plast og tre) og hastighet.

Bilde 1 viser en gruppe ungdomsskoleelevers arbeidstegning av en flåte. Innledningsvis jobbet elevene individuelt med sine idéer. Deretter ble de fordelt på fire grupper, og presenterte idéene sine for hverandre, lyttet til medelevenes idéfremlegg, stilte spørsmål, diskuterte og argumenterte for sin idé for å sammen enes om ett flåtekonsept. Elevene skulle også sette opp budsjett og foreta styrkeberegninger av materialkonstruksjonene. Elevene fikk dernest besøk av to ingeniører fra den deltakende industribedriften. Hver gruppe presenterte sin idé for ingeniørene, som hjalp dem med videreutvikling gjennom å gi råd og stille spørsmål. At elevene fikk hjelp av ingeniørene etter å ha tegnet flåtene og ikke i forkant, var et bevisst valg. Hadde ingeniørene forklart krav til oppdrift, tyngdepunkt og ulike typer rør før elevene var i gang, kunne dette blitt for abstrakt og 
vanskelig å forstå. Neste steg i prosessen var at ingeniørene produserte arbeidstegninger og 3D-illustrasjoner av gruppenes flåter. Etter at en siste runde med endringer ble gjort, var ungdomsskoleelevene klare for å ta med tegningene til yrkesfagklassen.
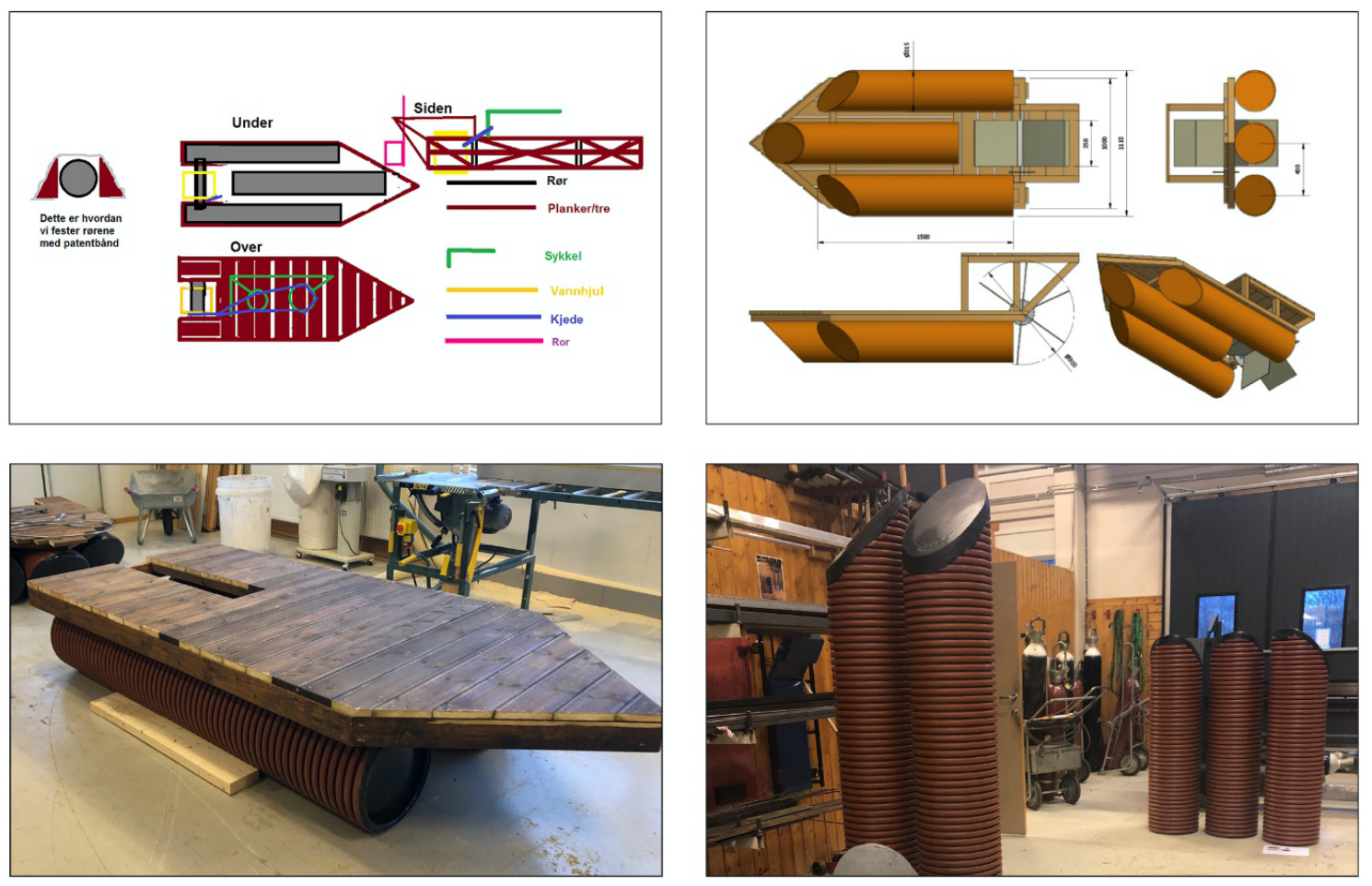

Bilde 1. Viser ungdomsskoleelevenes arbeidstegning, deretter bedriftens arbeidstegninger, og bilder av flåtene under bygging.

I sitt første møte med elever ved videregående skole presenterte gruppene oppgavene sine og fortalte om hvordan de hadde jobbet så langt. Ungdomsskolelæreren presiserte at når yrkesfagelevene nå skulle delta, var det viktig at de gjennom dialog med ungdomsskoleelevene bidro med ytterligere idéer og forslag til endelig utforming av flåten. Lærerne ønsket å engasjere alle elevene i arbeidet med å finne de gode løsningene. Ti yrkesfagelever deltok, og de ble fordelt inn $\mathrm{i}$ de fire opprinnelige gruppene. På dette første møtet så vi at yrkesfagelevene tok initiativ og ansvar for omvisning, og viste fram ulike verktøy, maskiner og materialer.

Arbeidet med å bygge flåtene foregikk på verkstedene for yrkesfagklassene. Bedriften leverte rør til flåtene, og etter initiativ fra lærerne ble en annen lokal bedrift leverandør av treverk. Dermed ble en byggfagklasse også involvert i deler av arbeidsprosessen. Både ungdomsskoleelevene og yrkesfagelevene var ivrige på å finne ulike løsninger til fremdriftssystem på flåten, og flere tok med verktøy og maskiner hjemmefra som de testet om kunne benyttes. 
Elevene møttes jevnlig i løpet av skoleåret 2018/2019, men arbeidet var mest konsentrert fra slutten av november til slutten av januar. I denne perioden møttes de ukentlig, med økter på cirka 2,5 timer. Yrkesfagelevene fungerte som veiledere for ungdomsskoleelevene, med hjelp fra lærerne ved behov. Gjennom å dele sin kunnskap med andre, ble de mer bevisst på hvor mye de hadde lært siden overgangen til videregående skole, noe som ga motivasjon for oppgaven. Arbeidslivsfaget hadde gitt ungdomsskoleelevene litt praktisk erfaring fra før, og de fleste ønsket å prøve seg på verktøyene og maskinene som var til rådighet i verkstedet på den videregående skolen. Elevene var aktive, og flere av dem viste stor selvstendighet på noen arbeidsoppgaver. Selv om gruppene hadde arbeidstegninger å forholde seg til var det nødvendig med diskusjoner underveis, både ungdomsskoleelevene og yrkesfagelevene imellom, og mellom elevene og ingeniørene fra bedrift. Flåtene ble dermed endret underveis etter hvert som elevene erfarte hva som fungerte og ikke.

En forsker observerte deltagerne gjennom fem arbeidsøkter: én økt hvor ungdomsskoleelevene og ingeniører fra bedriften jobbet med idéutvikling, én økt hvor elevene presenterte sine idéer for yrkesfagelever, og tre økter hvor elevene fra ungdoms- og videregående skole jobbet med oppgaven på skolens verksted. Målet med observasjonene var å se hvordan partene jobbet og hvordan de opplevde deltakelsen, samt å se hvordan organiseringen fungerte. I tillegg la observasjonene et godt grunnlag for utviklingen av intervjuguiden til dybdeintervju med elevene, som presenteres i neste kapittel.

\section{Utvalget}

I denne studien har åtte ungdomsskoleelever, fem yrkesfagelever fra VG2 Industriteknologi, en ansatt i deltagende industribedrift, en ungdomsskolelærer, en yrkesfaglærer og en avdelingsleder fra yrkesfag blitt intervjuet. Lærerne valgte ut de elevene som ble intervjuet, og var strategiske i sitt valg ved å sørge for at elever med ulike erfaringer ble intervjuet, ikke kun de som opplevde prosjektet utelukkende positivt.

\section{Forskningsintervjuet}

Kvalitativ metode kan gi innsyn i informantens opplevelser i en personlig og sosial kontekst, samt bidra til ny innsikt og kunnskap om forholdene og faktorene rundt som har en betydning for disse opplevelsene (Kvale \& Brinkmann, 2009). Forskningsintervju er en anerkjent metode og godt egnet for eksplorerende forskning der det i utgangspunktet ikke eksisterer så mye kunnskap (Braun \& Clarke, 2006; Kvale, 1983), slik som tematikken for denne studien.

For å få kjennskap til informantenes perspektiver og erfaringer hadde vi en viss grad av struktur på intervjuet ved å ha relative åpne spørsmål, men med fokus på spesifikke situasjoner og handlingssekvenser. Semistrukturerte intervjuer er fordelaktig både til individuelle intervjuer og gruppeintervjuer, og den 
største styrken til denne strukturen er dens fleksibilitet til å følge informantenes besvarelser. I et tradisjonelt gruppeintervju setter intervjueren fokus og bærer samtalen videre ved hjelp av en intervjuguide. Her er dialogen i stor grad mellom forskeren og de ulike deltagerne. Gjennom interaksjon forsker-deltagere fikk vi i gruppeintervjuene meningsutvekslinger som ga videre refleksjon blant deltagerne. De gjennomførte gruppeintervjuene ga tilgang til et bredere syn på erfaringer rundt noen spesifikt tema. Vi fikk dermed tilgang på rikere informasjon enn hva som ville kommet frem i individuelle intervjuer.

Kvalitet i kvalitativ forskning måles ofte ved å se på dens troverdighet (gyldighet, pålitelighet og overførbarhet) (Lincoln \& Guba, 2000). Gyldighet sier noe om i hvilken grad resultatene fra analysen samsvarer med spørsmålene i problemstillingen og om metodevalget er passende (Kvale \& Brinkmann, 2009). Pålitelighet forteller noe om hvor konsistent og troverdig forskningsresultatene er (Kvale \& Brinkmann, 2009). Overførbarhet viser til generaliserbarheten av funnene. Generaliserbarhet i kvalitativ forskning vil ikke si å generalisere universelt, men å undersøke om den kunnskapen som produseres i intervjuer, kan overføres til andre relevante situasjoner (Kvale \& Brinkmann, 2009). En analytisk generalisering er høyst relevant i dette forskningsprosjektet da det involverer en begrunnet vurdering av i hvilken grad funnene fra denne studien kan brukes som en rettledning for hva som kan fungere i en annen lignende setting (Kvale \& Brinkmann, 2009). Det er mottagerne av informasjonen selv som aktivt vurderer om funnene er gyldige for deres situasjon (Greenwood \& Levin, 2005). En annen kvalitetsindikator er forskningsprosessens transparens. Transparens handler om hvordan forskerne formidler de valgene de har gjort underveis i studien. Aktiv bruk av sitater og beskrivelser av analysevalg er en måte å sikre transparens.

\section{Tematisk analyse}

I denne studien har vi benyttet en tematisk analysemetode for å tolke og analysere datamaterialet. Tematisk analyse er en metode for å identifisere, analysere og rapportere tema og mønster i datamaterialet (Braun \& Clarke, 2006). Tematisk analyse gir en stor grad av metodisk fleksibilitet som gir god innsikt i et rikt datamateriale (Clarke et al., 2015). Analysen er preget av en abduktiv tilnærming som representerer en kontinuerlig prosess hvor en benytter både analyse fra data og inspirasjon fra teori samtidig som en utvikler nye perspektiver underveis fra analysen. Altså en blanding mellom en induktiv og en deduktiv analysetilnærming.

Den gjennomførte analysen tar utgangspunkt i retningslinjene som omfatter seks rekursive faser, som betyr at en kan bevege seg frem og tilbake mellom de seks fasene; (1) familiarisering (bli bedre kjent med dataene), (2) utvikle koder, (3) søke etter temaer, (4) gjennomgang av temaer, (5) definere og navngi temaene (hovedfunn) og til slutt (6) redegjøre for temaene i et skriftlig verk (rapportering). Fase 1 og 2 legger selve grunnlaget for analysearbeidet. Et grundig arbeid i disse 
fasene har betydning for hvor gode og empirinære temaene blir. Et tema innehar informasjon som er viktig relatert til forskningsspørsmålene. Hovedfokus for denne studien er hvordan samarbeidet mellom ungdomsskole, videregåendeskole og industri bedrift kan foregå for at det skal ha en nytteverdi for alle parter, men med et spesielt fokus på ungdomsskoleelevene og yrkesfagelevene.

Fase 3 til 6 er selve kjernen i analysearbeidet hvor en beveger seg fra koding til utvikling av tema basert på kodene. Etter en gjennomgang av alle kodene begynner dannelsen og struktureringen av tema hvor målet er å skape en plausibel og sammenhengende tematisk kartlegging av datamaterialet. Temaer anses som meningsfulle grupperinger av koder. En analyse av tematiske likheter ble gjennomført før en til slutt satt igjen med noen tema som hovedfunn. Hovedtemaene skal ha en meningsfylt rød tråd og være i relasjon til hverandre, men ha indre konsistens og på samme tid skille seg tematisk fra de andre tematiske gruppene. Den endelige tematiske analysen er klar når temaene er tydelig definert og navngitt (Braun \& Clarke, 2006).

Det krever en systematikk i selve kjernearbeidet i en analyse hvor hensikten er å redusere tekstmengder til koder samt heve kodene til tema. Intervjunotatene er selve datamaterialet. De ble gjennomgått grundig med den hensikt å utvikle koder. I fase 2 av analysen ble koder utviklet. To forskere arbeidet sammen for å trekke ut de meningsenheter som hadde relevant innhold. Søken etter tema resulterte $\mathrm{i}$ at koder som samsvarte og var nærliggende hverandre ble samlet.. I fase 3 av analysen gikk en da fra å samle koder til 6 tema. Gjennomgang av tema og vurdering av dets innhold er essensen i fase 4 og 5 . Noen tema ble slått sammen og dette resulterte i 3 hovedtema og 6 undertema.

\section{Etiske betraktninger}

Alle elevene mottok et informasjonsskriv hvor det ble redegjort for formålet med studien, forskningsetiske hensyn, personvern og rettigheter. Til de elvene som gikk på ungdomsskolen ble informasjonsskriv sendt til foreldrene, som signerte på at de godkjente elevens deltagelse. Det ble likevel understreket overfor elevene at de ikke måtte delta selv om foreldrene hadde godkjent det. Informert samtykke ble signert før intervjuene. Studien er innmeldt og godkjent av personvernombudet for forskning ved Norsk Samfunnsvitenskapelig datatjeneste.

\section{Resultat og diskusjon}

Den tematiske analysen resulterte i seks hovedtema (Tabell 1) som viser hvordan et samarbeid mellom ungdomsskole, videregående skole og industribedrift kan skape nytteverdi for alle involverte parter, men da med et spesielt søkelys på ungdomsskoleelevene (USE) og yrkesfagelevene (YFE) og hvordan nytteverdien av samarbeidet kan hjelpe ungdomsskoleelever til å ta et mer kvalifisert utdanningsvalg. 
Sylvi Thun, Linn Thøring \& Lisbeth Øyum

Tabell 1. En oppsummering av den tematiske analysen: hovedtema og undertema.

\begin{tabular}{lll}
\hline $\begin{array}{l}\text { Et innblikk i fremtidens } \\
\text { skole- og arbeidshverdag }\end{array}$ & $\begin{array}{l}\text { Synliggjøring av } \\
\text { elevenes } \\
\text { læringspotensial }\end{array}$ & $\begin{array}{l}\text { Utfordring av dagens } \\
\text { og fremtidens } \\
\text { kompetansebehov }\end{array}$ \\
\hline Relevant praktisk erfaring & $\begin{array}{l}\text { Engasjerende og } \\
\text { utfordrende } \\
\text { læringssettinger }\end{array}$ & $\begin{array}{l}\text { Tidlig erfaring med an- } \\
\text { svarskompetanse }\end{array}$ \\
$\begin{array}{l}\text { Andre (nye) former for } \\
\text { samarbeid og arbeidsrettet } \\
\text { kommunikasjon }\end{array}$ & $\begin{array}{l}\text { Den meningsfylte } \\
\text { skolehverdag }\end{array}$ & $\begin{array}{l}\text { Tidlig erfaring med in- } \\
\text { novasjonsaktivitet }\end{array}$ \\
\hline
\end{tabular}

Innblikk i fremtidens skole- og arbeidshverdag

Temaet et innblikk i fremtidens skole og arbeidshverdag består av undertemaene relevant praktisk erfaring og opplevelsen av andre (nye) former for samarbeid og arbeidsrettet kommunikasjon.

Relevant praktisk erfaring. Ungdomsskoleelevene ble utfordret til å tenke etter hvorfor de ønsket å bli med på prosjektet, og var tydelig på at praktiske erfaringer samt nye utfordringer var en trigger, som illustrert i de påfølgende sitatene: "Lyst på praktisk utfordring, litt større enn å lage en liten hylle" (USE). "Virket artig, hørtes mer interessant ut [praktisk oppgave] enn det andre [helse]." "Bli med fordi det er gøy å gjøre noe annet, interessant" (USE). Yrkesfagelevene var også interessert i prosjektets innhold og muligheter: "Virket interessant, artig å prøve noe nytt" (YFE). "Blir litt tenkning utenom det vanlige, både trevare og plastikk" (YFE). I tillegg ønsket yrkesfagelevene å vise andre hvordan det er å gå yrkesfag, og bidra til å heve antall søkere: "For å prøve noe annet, se hvordan vi kan påvirke elevene til å velge yrkesfag. Jobbe fysisk, være litt lærere" (YFE). Seks av de åtte ungdomsskoleelevene som ble intervjuet opplevde at de hadde blitt mer sikre på at yrkesfag ville være rett valg på videregående skole. Samarbeidet i prosjektet og den praktiske erfaringen ga mersmak: "Fikk mer lyst etter at jeg så hva de holdt på med, sveising og sånn" (USE). "Lyst til å gjøre noe praktisk, det jeg liker å gjøre" (USE).

Elevene tok selv valget om å delta i prosjektet, basert på egne interesser og ønsker. Dette viser en autonom motivasjon for å delta, noe som ifølge selvbestemmelsesteorien vil kunne påvirke skolegangen positivt, og som ifølge forskning predikerer skolenærvær og vedholdenhet, gjennomføringsgrad, skoletilfredshet, prestasjoner og måloppnåelse (Guay et al., 2008). De forteller om at praktisk arbeid er noe de synes er gøy og ønsker å lære mer om, noe som viser behovet for å bruke og utvikle sin kompetanse og mestre omgivelsene. Å få behovet for å oppleve kompetanse tilfredsstilt, vil ha en positiv effekt på elevenes autonome motivasjon. Den positive innstillingen til arbeidet de skal gjøre, viser 
også at de har en klar forventning om mestring, noe som kan føre til at de jobber hardere og viser mer utholdenhet, viser større interesse for å lære, og lærer mer (Bandura, 1977; Moos \& Azevedo, 2009). At elevene er opptatt av praktisk arbeid og ønsker å lære mer, er positivt for utviklingen av ferdigheten basisfag (den yrkesfaglige utdanningen fra videregående skole og læretiden), som det er viktig at fagarbeideren har (Solem et al., 2016).

Samarbeid og arbeidsrettet kommunikasjon. Ungdomsskoleelevene ga uttrykk for at det var spennende med nye samarbeidsformer (samarbeid på tvers av fag, alder og roller) og at dette også forsterket interessen for prosjektet: "Bli kjent med nye folk og se på hva de holder på med på her, bli bedre på å samarbeide" (USE). "Også samarbeide med næringslivet" (USE). Selv om de hadde en bevissthet om at samarbeid ikke alltid er enkelt, var dette en utfordring de tok på strak arm: "At vi skulle jobbe sammen, samarbeidsoppgaver kan være mer krevende" (USE). "Det har vært gøy. ALT" (USE). Ungdomsskoleelevene var spente på hvordan det ville bli å samarbeide med de som var eldre, men erfaringen ble positiv: "Samarbeidskompetansen har blitt bedre. Blitt bedre kjent med hverandre" (USE). "Lært at samarbeid med eldre går bra. Det trodde jeg ville bli et problem siden de er eldre. Men det gikk veldig bra" (USE). Yrkesfagelevene fikk skryt fra lærerne av hvor godt de hadde tatt seg av ungdomsskoleelevene: "De tok godt imot dem. Tok jobben seriøst. Var aldri noe høyt konfliktnivå. Stahet, men i positiv forstand. Ungene opptrådde respektfullt. " Yrkesfagelevene selv ga også uttrykk for at prosjektet ga dem nye samarbeidserfaringer og at det var gøy å samarbeide. "Tar med oss videre at vi kan løse ting sammen i lag" (YFE).

$\AA$ ha en arbeidsrettet dialog med bedriften via e-post var uvant for ungdomsskoleelevene, men en god erfaring, ifølge læreren: "Samspill via mail var ukjent for dem. Denne utfordringen ble etter hvert opplevd som nyttig."

Som sitatene illustrerer så var det en viss usikkerhet rundt det å samarbeide med eldre. I kombinasjon med nye utfordringer og dårlig mottakelse hadde et slikt prosjekt lidd. Men det at yrkesfagelevene støttet og ivaretok ungdomsskoleelevene såpass godt, bidro til å dekke behovet for tilhørighet (Deci et al., 1992). Også yrkesfagelevene lærte at man kunne løse problemer sammen. Både ungdomsskoleelevene og yrkesfagelevene følte tilknytning til dem de samarbeidet med og opplevde at alle vil hverandre vel og hadde gjensidig respekt for hverandre. A kjenne tilhørighet vil ha en positiv innvirkning på elevenes autonome motivasjon.

Motivasjon må, ifølge sosial-kognitiv læringsteori, være til stede for at læring skal skje, og læring skjer gjennom egne erfaringer, oppfattelser, tanker og observasjoner (Bandura, 1986, 2012). Læring skjer både gjennom at man selv for eksempel utfører praktisk arbeid, og at man observerer andres arbeid. Forholdene mellom en persons kognitive egenskaper, personens miljø og personens atferd eller handlinger påvirker hverandre, og når det gjelder læring så påvirkes dermed eleven av både indre og ytre faktorer. Siden både ungdomsskoleelever og 
yrkesfagelever beskriver samarbeidet som godt, vil man kunne si at miljøet hadde en positiv innvirkning på prosessen. Evnen til å kommunisere og samarbeide godt er viktig for fremtidens fagarbeider, og slik har prosjektet bidratt til å utvikle en egenskap elevene trenger i arbeidslivet (Solem et al., 2016).

\section{Synliggjøring av elevenes læringspotensial}

Et annet hovedtema er synliggjøring og utvikling av elevenes potensial. Dette hovedtemaet består av undertemaene engasjerende og utfordrende læringssettinger og den meningsfylte skolehverdag.

Engasjerende og utfordrende laringssettinger. Gjennom prosjektet fikk elevene en økt bevissthet om hvordan utfordringer henger sammen med læring: "Har vært læring å møte på de utfordringene" (USE). Sammen med motiverende og utfordrende settinger, skapte realistiske tilbakemeldinger mestringsopplevelser. "Bra å få tilbakemelding (fra bedrift) om hva vi kunne forbedre" (USE). "Fikk se paint-tegningene i 3D. Det ble veldig motiverende å se hvor kult det ble" (USE). Men ikke alle utfordringene var positive opplevelser. I likhet med ungdomsskoleelevene hadde også yrkesfagelevene kontakt med bedriften via e-post, men da etter at prosessen med å bygge flåtene var i gang. Tegningene manglet noe informasjon på detaljnivå, og noe av det som var tegnet mente yrkesfagelevene at ikke lot seg gjennomføre. Det at tegningene fra bedriften ikke var helt komplette, viste seg i etterkant å være bevisst fra ingeniørenes side. Dette fordi de ikke ville gi elevene en "fasit", men heller gi dem muligheten til å prøve og feile, og tenke og gjøre endringer underveis selv.

I henhold til selvbestemmelsesteorien og sosial-kognitiv teori vil det å sette krav og utfordre elevene ha positiv effekt så lenge det er satt i et rammeverk som fremmer autonom motivasjon og mestringsforventning. Dialogen og tilbakemeldingene fra bedriften var også med på å bygge elevenes mestringsforventning $\mathrm{i}$ en tidlig fase av prosjektet. A skape de settingene hvor eleven blir utfordret $\mathrm{i}$ trygge omgivelser er med på å bygge elevens ressurslager. Autonom motivasjon og mestringstro setter i gang en positiv spiral for læring og utvikling. Yrkesfagelevene hadde nok en forventning om at tegningene fra bedriften skulle være feilfrie, og opplevde dermed frustrasjon når tegningene ikke var så gode som forventet. Hadde man på et tidlig tidspunkt avklart med elevene at tanken var at de skulle prøve seg frem selv, og at dette ville være god læring, hadde elevene sett på utfordringene som en naturlig del av arbeidet. Dette kan knyttes til det man i sosial-kognitiv læringsteori kaller selvregulert læring, hvor eleven selv tar ansvar for deler av læringsprosessen, og blant annet planlegger og gjør vurderinger underveis (Skaalvik \& Skaalvik, 2013).

Den meningsfylte skolehverdag. Å skape de meningsfylte (og litt annerledes) settingene i skolehverdagen kan være en utfordring, men øke læringsutbyttet og gi betydningsfull erfaringslæring med en positiv smitteeffekt. En ungdomsskoleelev som allerede hadde erfaring med praktisk arbeid og spesiell interesse for 
tematikken i prosjektet påpekte at han ikke hadde lært noe nytt, men lært det bedre. Jevnt over var det stor entusiasme blant elevene, og de uttrykte at de hadde lart mye nytt (USE), fått prøve mye forskjellig (USE) og at det var gøy (USE). For mange var prosjektet noe de gledet seg til hver uke: "Mer givende skoledager når vi holdt på med prosjektet" (USE). "Praktisk er gøy" (USE). "Har noe å se fram til hver uke" (USE). "Var jo artig for oss også" (YFE). Flere fikk også en økt forståelse for nytten av teori, og det praktiske arbeidet ble et godt verktøy for å lære det teoretiske: "Gøy å regne noe en kan se. Artig med praktisk matematikk" (USE). "Gikk bedre å bruke matematikken, mye mer motiverende når vi hadde det praktiske og får noe ut av det, noe håndfast. Bruker jo matematikk hele tiden" (USE). "Var lettere å lære det (regne oppdrift) når det var praktisk relevant" (USE). "Lærerikt å se at de (yrkesfagelevene) stod og sveiset. De forklarte litt underveis." (USE). I tillegg var det flere elever som på eget initiativ tok med deler hjemmefra, noe som også viser hvor stort engasjementet var rundt prosjektet.

Ungdomsskolelæreren opplevde også at det var en viss overføringsverdi til andre fag. "Synes å se ut til at elevene jobber bedre i andre fag også." "I arbeidsplantimene satt de ihugget og jobbet. Mer meningsfull hverdag, håper det gir mer motivasjon framover." Han hadde vært tydelig overfor elevene om at dette var et nyttig prosjekt, og at han hadde tro på at de kunne få det til: "Det har blitt stilt krav til dem. Sier at jeg har tro på dem. Hvis ikke har jeg ikke startet på dette prosjektet. Da har vi laget fuglekasser." Læreren fortalte om elever som blomstret, noe ingeniørene fra bedriften også opplevde: "Synes det er artig å se de som blomstrer, og at det lyser i øynene på dem." Ungdomsskolelæreren ønsket at prosjektet skulle bidra til å gi en mer meningsfylt skolehverdag for elevene. I intervjuet delte læreren av sine erfaringer knyttet til dette: "Det ga dem mer mening på skolen, så fram til dette. Om en ikke har noe å se fram til annet enn fredag og helg, så gjør det noe med dem. Det er viktig å glede seg til noe, se at det kan realiseres. At det virkelig skal bli noe, ser verdien av det."

Ifølge selvbestemmelsesteorien kan lærerne i dette prosjektet sies å ha bidratt til å tilfredsstille elevenes behov for både autonomi, tilhørighet og kompetanse. Lærere er signifikante påvirkere ved utvikling av elevers autonome motivasjon (Deci et al., 1992). Lærere som involverer seg, og har en støttende og autonom lærerstil slik som ungdomsskolelæreren, bidra til en struktur hvor en kan få bedre internalisering av autonome læringsaktiviteter i utdanningskontekster (Deci et al., 1992; Guay et al., 2008). Sosial-kognitiv læringsteori støtter også opp under viktigheten av et godt miljø (som lærere og andre elever) for at læring skal kunne skje (Bandura 1986, 2012). Ungdomsskolelæreren viste elevene at han hadde tro på dem, og var støttende samtidig som han ga elevene reelle utfordringer, noe som bidro til å styrke elevenes forventning om mestring (Skaalvik \& Skaalvik, 2013).

Smitteeffekten av de meningsfylte oppgavene kan karakteriseres som en buffer, en faktor som gjør en rustet til å også stå i og "overleve" de mer kjedelige 
eller vanskelige oppgavene. I dagens skole er det et unyttet potensial i å skape de situasjonene som gir meningsfylte oppgaver. Veien til målet om å oppfylle alle krav i dagens læreplaner er muligens mer variasjon mellom de praktiske settingene og de rent teoretiske, i alle fall i større grad enn i dag.

\section{Fremtidens kompetansebehov}

Det siste hovedtemaet utfordring av dagens- og fremtidens kompetansebehov består av undertema erfaring med ansvarskompetanse og erfaring med innovasjonsaktivitet.

Ansvarskompetanse. I løpet av prosjektet opplevde elevene, spesielt yrkesfagelevene, situasjoner hvor det ble utfordrende å skulle være selvstendig, og ta ansvar for egen og andres arbeidsinnsats og medvirkning. Ikke alle erfaringene var like heldige, som påfølgende sitater viser: "Må passe på at ikke alt ansvar faller på enkeltelever" (YFE). "Var vanskelig å være (ha ansvar) alene om en gruppe" (YFE). "Ungdomsskoleelevene så på det som en selvfølge at jeg skulle lage fremdriften" (YFE). "Planlegge og ordne selv, det fungerte ikke helt" (YFE). Opplevelsene bekreftes av yrkesfaglæreren, som fortalte om at enkelte hadde kjent på ansvaret som en byrde, både når det gjaldt framgang i byggeprosessen og det å finne gode løsninger. Samtidig opplevde yrkesfagelevene prosjektet som lærerikt og nyttig. Gjennom det ansvaret de hadde i prosjektet, ble de bevisst på hvor langt de hadde kommet siden de selv var ungdomsskoleelever, og hvor mye de kunne om faget sitt. Spesielt de situasjonene der de måtte gjøre vurderinger, argumentere og forklare hvorfor noe måtte gjøres på en spesiell måte, hadde god læringseffekt: "Lærte litt om faget. Må forenkle budskapet" (YFE). "Måtte prøve å argumentere for hvorfor det ikke ville fungere. Jeg prøvde å argumentere hvorfor, men elevene [USE] var litt sta på sitt" (YFE). "Ser at en har kommet lengre" (YFE). "De [USE] viste interesse for faget" (YFE).

Ansvarskompetanse omhandler en evne til å medvirke i viktige beslutningsprosesser, ta ansvar for egen arbeidsplass, egen og andres arbeidsinnsats, og arbeide selvstendig uavhengig om det er en leder til stede eller ikke, som overvåker situasjonen (Ravn, 2017). Slik sitatene beskriver er ansvarskompetanse og dets elementer ikke alltid opplevd som kvalifikasjoner ensbetydende med et positivt utfall. Når en snakker om fremtidens fagarbeider vil begrepets innhold være noe å strekke seg etter, på samme tid kan det virke skremmende. Det å ta ansvar kan oppleves som et tveegget sverd på grunn av modenhet og grad av selvstendighet. Om man ikke føler seg rustet for oppgaven, kan ansvar være belastende. Ser man elevenes erfaringer med ansvar i sammenheng med selvbestemmelsesteorien, kan det å oppleve en oppgave som en byrde som noen andre har pålagt en, bidra til at man utvikler kontrollert motivasjon, noe som kan påvirke læringssituasjonen negativt. Man kan også si at behovet for kompetanse ikke alltid ble tilfredsstilt. I noen situasjoner opplevde elevene å ikke strekke til, mens andre ganger mestret de å støtte og veilede ungdomsskoleelevene, slik at de riktige avgjørelsene ble tatt og prosjektet ble drevet fremover. Videre vil følelsen av å ikke 
strekke til, påvirke elevens mestringstro negativt. Får man derimot ansvar som man kan stå i ut fra de forutsetningene man har, og oppgaver i riktig vanskelighetsgrad, vil forventningen om mestring øke (Skaalvik \& Skaalvik, 2013).

Innovasjonsaktivitet. En av yrkesfagelevene beskrev prosessen med flåtebyggingen slik: "Vi fikk være mer kreative. Improvisere. Tenke nye løsninger." Gjennom prosjektet lærte elevene å bruke erfaringene sine til å løse problemer etter hvert som de oppsto. De måtte tenke nytt og videreutvikle flåtene underveis. Slik bidro prosjektet til å utvikle innovasjonsevne, en egenskap som er viktig for fremtidens fagarbeider (Solem et al., 2016). Så lenge elevene opplever en slik frihet i arbeidsprosessen som noe positivt, og ikke synes det er for vanskelig eller krevende, vil muligheten til å sette sitt preg på arbeidet, være kreativ og tenke nytt, bidra til at de får tilfredsstilt behovet for autonomi og kompetanse, og utvikler autonom motivasjon (deCharms, 1968; Deci et al., 1992). Videre vil denne friheten, og erfaringen om at man har den erfaring og kunnskap som trengs, bidra til at man utvikler mestringstro, blir agent i eget liv og styrer og regulerer sin egen læring (Bandura, 2005).

\section{Oppsummering av hovedfunn}

Hovedfunnene i denne artikkelen er at et innovasjonsrettet samarbeid mellom ungdomsskole, videregående skole og en industribedrift bidrar til at elevene opplever et innblikk i fremtidens skole- og arbeidshverdag, ser sine egne læringspotensialer tydeligere og gir erfaring med fremtidens kompetansebehov. Dette gjennom praktisk erfaring, nye former for samarbeid og arbeidsrettet kommunikasjon, læringsituasjoner som er engasjerende og utfordrende, samt bidrar til en opplevelse av mening, og erfaring med å ta ansvar for egen og andres læring. Totalt sett bidrar dette med at elevene kan oppleve å ta et mer kvalifisert utdanningsvalg. Elevene opplever mer autonom motivasjon (handling drevet av en følelse av egen vilje og valg) enn kontrollert motivasjon (handling som er drevet av en følelse av press). Resultatene har fremhevet at elevene har opplevd positive utfall, både atferdsmessige, kognitive og affektive, på skolen. Dette er i tråd med både selvbestemmelsesteorien og tidligere forskning, som viser at autonom motivasjon er bedre for skolenærværet, skoletilfredshet, prestasjoner og måloppnåelse (Deci \& Ryan, 2008; Guay et al., 2008).

Prosjektet er også konstruert på en slik måte at det etterstreber selvregulert læring - en læringsprosess som omhandler egen målsetning, vurderinger av prosess fra start til slutt, egenrefleksjon, vurdering og evaluering. Prosjektet bygger opp om individets tro på at en har evne til å ta kontroll over eget liv, være agent i eget liv, slik som Bandura (2005) illustrerer. Resultatene viser at elevene har økt sin mestringstro og at de gjennom prosjektet har erfart at de kan tilegne seg avansert kunnskap, for eksempel avansert matematikk gjennom praksis. Arbeidsrettet praksis motiverer elevene til å tilegne seg både fagspesifikk og generisk kompetanse (Øyum et al., 2019). Både sosial-kognitiv teori og selvbestemmelsesteori 
fremhever at motivasjon er sensitiv på kontekst. Er det slik at dagens skole er for kontrollerende og mangler rom for å kunne gi de gode erfaringene som fremmer læring gjennom autonom motivasjon og mestringstro?

Det er tydelig at elevenes opplevelser og erfaringer har betydning for hvor mye nytte en opplever av et slikt innovativt samarbeid i arbeidslivsfag. Bakken et al. (2012) rapporterte i sin studie at arbeidslivsfaget foregikk for lite "ute i det virkelige livet", ga ungdommene for få praktiske erfaringer utenfor skolesettingen, hadde lite utplasseringer, bedriftsbesøk og jobbing utenfor skolen. I prosjektet "Fra fjortis til fagarbeider" har elevene blant annet erfart mye praktisk arbeid, møtt samarbeidspartene i bedrift, og jobbet $i$ andre arenaer enn klasserommet. Dette har bidratt til et prosjekt hvor alle parter har vært fornøyde og sitter igjen med mange positive erfaringer og nytteverdi. Et innovativt samarbeid mellom ungdomsskole, videregående skole og bedrift, har et ubenyttet potensial i landets skoler.

\section{Praktiske implikasjoner}

Dette innovasjonsprosjektet har bidratt til at alle de involverte aktørene har opplevd en form for nytte. Ungdomsskoleelevenes nytteverdi var innblikk i yrkesfag og arbeidslivet for å kunne ta et kvalifisert utdanningsvalg (det vil si å få et bilde av hva det vil si å utdanne seg til fagarbeider og hvordan arbeidslivet kan se ut, før de må foreta utdanningsvalget). Yrkesfagelevene opplevde en økt bevissthet om egen kunnskap, mer kjennskap til reelle samarbeidsformer, og et økt innblikk i arbeidslivet. Både ungdomsskoleelever og yrkesfagelever erfarte at de er i stand til å lære, og at læring er gøy når arbeidet føles nyttig og meningsfylt. Om man forventer at fremtidens fagarbeider skal være positivt innstilt til det å være i kontinuerlig utvikling gjennom hele arbeidslivet, er det viktig at man som skoleelev har gode opplevelser knyttet til det å lære.

Skolene fikk involvere elevene i meningsfylte og engasjerende oppgaver som ga dem verdifull erfaring. Videre fikk skolene utviklet en bedre samarbeidskompetanse og en økt bevissthet på hva som er viktig for at slike prosjekt skal føre til positive utfall og være en god opplevelse for elevene (for eksempel for å få et innblikk og ta et kvalifisert valg, som igjen kan bidra til å redusere frafall og feilvalg) og lærerne. Den videregående skolen fikk også vist fram skolen for mulige nye elever. Bedriftens opplevde nytteverdi er helt konkret rekruttering, det å være synlig for fremtidige arbeidstakere og å kunne påvirke innholdet $\mathrm{i}$ undervisningen for å tilpasse det til arbeidslivets behov.

Å få innblikk i erfaringer fra partene i samarbeidsforsøket har en stor praktisk betydning for implikasjonene en kan få ut av dette prosjektet og overføringsverdi til andre lignende prosjekter. Dette blir spesielt viktig med tanke på at nye læreplaner vektlegger at elevene skal få muligheten til å spesialisere seg tidligere enn i dag, og det elevene lærer på skolen, skal være relevant for arbeidslivet. Praktiske implikasjoner er oppdelt i tre underkategorier; (1) organisering av 
samarbeidet mellom ungdomsskole, videregående skole og bedrift, (2) eierskap og forankring og (3) forventningsavklaring.

Organisering av samarbeidet mellom ungdomsskole, videregående skole og bedrift. Et tett samarbeid med hyppige møtepunkter er lettere sagt enn gjort. Hvor vellykket et slikt samarbeid vil kunne være er avhengig av strukturen rundt og hvordan en organiserer samarbeidet. Det er tidkrevende og krever både eierskap, forankring og en tydelig forventningsavklaring. I de påfølgende avsnittene vil vi gå nærmere inn på dette, men først en kort oppsummering av de organisatoriske erfaringene til de samarbeidende partene. Deltagerne i dette samarbeidet har erfart at det organisatoriske tar krefter, og at det er en del begrensinger ved det timeplantekniske. I tillegg erfares det at det ikke er attraktivt å være lærer på arbeidslivsfag. Noe deltagerne trodde dette samarbeidet var umulig siden det er så "strikte" planer i skolen. Med til tross for disse erfaringene, har en lært at det er fullt mulig få til et godt samarbeid mellom en ungdomsskole, videregående skole og lokale bedrifter så lenge det er vilje og innsats samt oppleves at samarbeidet gir en nytteverdi.

Eierskap ogforankring. Det har stor betydning at alle ser nytteverdien av prosjektet, tar eierskap for å sørge for fremgang og fremdrift, og har fokus på å forankre prosjektet hos sine riktige nøkkelpersoner. Både yrkesfaglæreren og avdelingsleder for yrkesfag ved den videregående skolen understrekte at de har stor tro på at samarbeid med ungdomsskole og bedrift må til: "Viktig at de (elevene) vet nok til å velge rett for seg selv. Så viktig at vi er synlige og bidrar med den kompetansen. Få inn informasjon på et tidlig tidspunkt." "For oss er det godt og viktig å vise fram hva vi driver med." "Positivt at de ser bedriftene bryr seg om elevene, bruker tid og penger på oss, tar de seriøst." I tillegg ble kompetansen hos rådgivere i skolen trukket frem som viktig. Kanskje kan slike prosjekter være en god støtte i rådgivernes arbeid også.

Forventningsavklaring. En tydelig og tidlig forventningsavklaring er viktig for at et slikt innovativt samarbeid skal være optimalisert. Det må være tydelig hva hver part ønsker å få ut av prosjektet og hvem som har ansvar for hva. Et konkret eksempel fra dette prosjektet handlet om yrkesfagelevenes og bedriftens kommunikasjon om tegningene. Bedriften ga ungdomsskoleelevene god hjelp med tegningene, men ville ikke gi noen "fasit", da elevene også burde prøve seg frem og gjøre seg erfaringer selv. En slik tilnærming vil kunne gi god læring og være en naturlig del av arbeidet. Siden yrkesfagelevene ikke var klar over at dette var bevisst, førte det til en frustrasjon over planer som ikke var gjennomførbare. Dette kunne vært unngått om man på forhånd hadde avklart hvordan alle partene så for seg at prosjektet skulle foregå. Men på en annen side ga også dette bidrag til en god læringsprosess da en i det virkelige arbeidslivet vil møte på situasjoner hvor det ikke er like rett frem hva som er den rette løsningen og man må håndtere situasjoner som kan oppleves frustrerende. 


\section{Konklusjon}

Et innovativt samarbeid mellom ungdomsskole, videregående skole og industribedrift skaper nytteverdi for alle involverte, og da spesielt for elevene, som får verdifull erfaring som gir dem ferdigheter og egenskaper de trenger som fremtidens fagarbeidere. Elevene lærte nye begreper og ble kjent med nye former for samarbeid. De vokste på de utfordringene de møtte, fikk gode opplevelser knyttet til det å lære, de ble bevisst sin egenverdi og tryggere i sitt utdanningsvalg. Elevene opplevde både atferdsmessige, kognitive og affektive utfall som var positive for prestasjoner på skolen og erfaringer med skolehverdagen. De fikk erfare hva autonom motivasjon kan bety for skolenærværet, skoletilfredshet, prestasjoner og måloppnåelse. Skolene erfarte at det faktisk er mulig å få til et slikt samarbeid, og de lærte hvordan det bør organiseres for å gi positive utfall og være en god opplevelse for elevene. Bedriften fikk muligheten til å bli kjent med nye mulige arbeidstakere og bidra til å tilpasse skolens undervisning til arbeidslivets behov. Alle de involverte fikk kjenne på hvilke premisser som må ligge til grunn for et slikt samarbeid, og til tross for utfordringer og hindringer underveis, var de enige om at dette innovative prosjektet skapte en nytteverdi for alle.

\section{Slutnoter}

${ }^{1}$ Ikke alle elevene får tilbud om lærlingekontrakt i bedrift. Disse får tilbud om å gjennomføre videregående opplæring med å ta et tredje år, VG3, på skolen. Dette fører derimot ikke til fagbrev.

2Statistics Norway. https://www.ssb.no/vgogjen

${ }^{3} \mathrm{NAV}$ er en offentlig etat underlagt Arbeids- og sosialdepartementet som har ansvaret for organisering og finansiering av arbeidsmarkedstiltak, trygdeytelser og sosialhjelp.

${ }^{4}$ https://www.nho.no/siteassets/analyse/nhos-kompetansebarometer-2019 nifurapport2019.pdf

${ }^{5}$ https://www.udir.no/laring-og-trivsel/lareplanverket/fagfornyelsen/her-er-nyelareplaner---vg1-yrkesfag/

${ }^{6}$ Se nye læreplaner - Kunnskapsløftet 2020 (udir.no).

${ }^{7} \mathrm{Om}$ arbeidsrelevansmeldingen - regjeringen.no.

8 Home | KeyCoNet (eun.org).

9 Assessment \& Teaching of 21st Century Skills - ATC21S.

${ }^{10}$ Forskningsrådet: Kompetanseprosjektet SKILLS (norskindustri.no).

\section{Anerkjennelse til bidragsytere}

Vi ønsker å takke ungdommene som delte sine erfaringer med oss, øvrige informanter og samarbeidspartnere i SKILLS for deres deltagelse. Forskningsprosjektet "SKILLS - Fremtidens fagarbeider" er finansiert av Norges Forskningsråd og prosjektpartnere (prosjektnummer 247747). 


\section{Om forfatterne}

Sylvi Thun, PhD, forsker ved SINTEF Digital, Teknologiledelse, Trondheim, Norge. Hun har forsket på tema innen arbeids- og organisasjonspsykologi i over 10 år og har doktorgrad fra 2017 om forløpere til og konsekvenser av sykenærvær. I tillegg til doktorgradens tematikk er hun er opptatt av folks arbeidshverdag med fokus på forebyggende- og helsefremmende arbeidsmiljøarbeid, motivasjon og engasjement, arbeidsdesign og jobbforming (job crafting), og intervensjonsprosesser.

Linn Thøring, MSc, forsker ved SINTEF Digital, Teknologiledelse, Trondheim, Norge. Hun har en mastergrad i pedagogikk fra 2018. Hennes masteroppgave handlet om hvordan yrkesfaglige utdanninger og industribedrifter kan samarbeide for å gi lærlinger en god læretid og motivasjon til å fortsette i yrket som fagarbeidere.

Lisbeth Øyum, PhD, er seniorforsker ved SINTEF Digital, Teknologiledelse, Trondheim, Norge. Hun har i over 20 år forsket på det norske medvirkningssystemet, bedriftsutvikling, arbeidsmiljø, arbeidsprosesser og ledelse. Hun tok sin doktorgrad i 1999 innen temaet industrielt demokrati og bedriftsutvikling. Øyum har lang erfaring i å benytte aksjonsforskning som forskningsdesign. 


\section{Referanser}

Aakernes, N. (2018). From school to work: Coherence between learning in school and learning in workplaces for apprentices in the Media graphics programme in Norway. Nordic Journal of Vocational Education and Training, 8(1), 76-97.

Bakken, A., Dæhlen, M., Haakestad, H., Aaboen Sletten, M. \& Smette, I. (2012). Ett år med arbeidslivsfaget: Læreres og elevers erfaringer med arbeidslivsfaget på 8. trinn (NOVA Rapport nr 1/12). Velferdsforskningsinstituttet NOVA.

Bakken, A., Dæhlen, M. \& Smette, I. (2013). Forsøk med arbeidslivsfag på ungdomstrinnet: Sluttrapport fra en følgeevaluering (NOVA rapport 11/13). Velferdsforskningsinstituttet NOVA.

Bandura, A. (1977). Self-efficiacy: Toward a unifying theory of behavioral change. Psychological Review, 84(2), 191-215.

Bandura, A. (1986). Social foundations of thought and action: A social cognitive theory. Prentice Hall.

Bandura, A. (2005). Adolescent development from an agentic perspective. I F. Pajares \& T. Urdan (Red.), Self-efficiacy beliefs of adolescents (s. 1-43). Information Age Publishing.

Bandura, A. (2012). On the functional properties of perceived self-efficacy revisited. Journal of Management, 38(1), 9-44.

Baumeister, R. F. \& Leary, M. R. (1995). The need to belong: Desire for interpersonal attachments as fundamental human motivation. Psychological Bulletin, 117(3), 497-529.

Braun, V. \& Clarke, V. (2006). Using thematic analysis in psychology. Qualitative Research in Psychology, 3(2), 77-101.

Clarke, V., Braun, V. \& Hayfield, N. (2015). Thematic analysis. I J. A. Smith (Red.), Qualitative psychology: A practical guide to research methods (s. 222-248). Sage Publications.

Bunting, M. \& Moshuus, G. H. (2017). Young peoples' own stories about dropping out in Norway: An indirect qualitative approach. Acta Didactica Norge, 11(2). https://doi.org/10.5617/adno.3182

Deci, E. L. \& Ryan, R. M. (1985). Intrinsic motivation and self-determinism in human behaviour. Plenum Press.

Deci, E. L. \& Ryan, R. M. (2000). Self-determination theory and the facilitation of intrinsic motivation, social development, and well-being. American Psychologist, 55(1), 68-78.

Deci, E. L. \& Ryan, R. M. (2008). Self-determination theory: A macrotheory of human motivation, development and health. Canadian Psychology, 49(3), 182185.

Deci, E. L., Vallerand, R. J., Pelletier, L. G. \& Ryan, R. M. (1991). Motivation and education: The self-determination perspective. Educational Psychologist, 26(34), 325-346. 
Deci E. L., Hodges, R., Pierson, L. \& Tomassone, J. (1992). Autonomy and competence as motivational factors in students with learning disabilities and emotional handicaps. Journal of Learning Disabilities, 25(7), 457-471.

deCharms, R. (1968). Personal causation. Academic Press.

Falch, T., Borge, L.-E., Lujala, P., Nyhus, O. H. \& Strøm, B. (2010). Årsaker til og konsekvenser av manglende fullføring av videregående opplæring. (SØF-rapport 03/10). Senter for økonomisk forskning AS.

Gagné, M. \& Deci, E. L. (2005). Self-determination and work motivation. Journal of Organizational Behaviour, 26, 331-362.

Greenwood, D. J. \& Levin, M. (2005). Introduction to action research. Sage Publications.

Guay, F., Ratelle, C. F. \& Chanal, J. (2008). Optimal learning in optimal contexts: The role of self-determination in education. Canadian Psychology, 49(3), 233240.

Kvale, S. (1983). The qualitative research interview: A phenomenological and a hermeneutical mode of understanding. Journal of Phenomenological Psychology, 14(2), 171-196.

Kvale, S. \& Brinkmann, S. (2009). Det kvalitative forskningsintervju (2. utgave). Gyldendal akademisk.

Levin, M., Nilssen, T. G., Elvemo, J. \& Øyum, L. (2012). Demokrati i arbeidslivet: Den norske samarbeidsmodellen som konkurransefortrinn. Fagbokforlaget.

Lincoln, Y. S. \& Guba, E. G. (2000). Paradigmatic controversies, contradictions, and emerging confluences. I N. K. Denzin \& Y. S. Lincoln (Red.), Handbook of qualitative research (s. 163-188). Sage Publications.

Messmann, G. \& Mulder, R. H. (2011). Innovative work behaviour in vocational colleges: Understanding how and why innovations are developed. Vocations and Learning, 4(1), 63-84.

Moos, D. C. \& Azevedo, R. (2009). Self-efficacy and prior domain knowledge: To what extent does monitoring mediate their relationship with hypermedia learning? Metacognition and Learning, 4(3), 197-216.

Multon, K. D., Brown, S. D. \& Lent, R. W. (1991). Relation of self-efficacy beliefs to academic outcomes: A meta-analytic investigation. Journal of Counseling Psychology, 38(1), 30-38.

NOU 2014:7. (2014). Elevenes læring i fremtidens skole: Et kunnskapsgrunnlag. Kunnskapsdepartementet. https:/ / www.regjeringen.no/no/dokumenter/NOU-2014-7/id766593/

NOU 2018:2. (2018). Fremtidige kompetansebehov I, Kunnskapsgrunnlaget. Kunnskapsdepartementet. https:/ / www.regjeringen.no/no/dokumenter/nou-2018-2/id2588070/

Olafsen, A. H. (2018). Selvbestemmelsesteorien: Et differensiert perspektiv på motivasjon i arbeidslivet. Magma, 2, 54-61. 
Pajares, F. (2006). Self-efficacy during childhoods and adolescence: Implications for teachers and parents. I T. Urdan \& F. Pajares (Red.), Self-efficacy beliefs of adolescents (s. 339-367). IAP.

Ravn, J. (2017). Ansvarskompetanse (SINTEF-rapport 2017:00336). SINTEF. http:/ / hdl.handle.net/11250/2488300

Ravn, J. \& Øyum, L. (2018). Towards 'multi-collar' unionism: Cases of trespassing professionals in Norwegian industrial relations. Economic and Industrial Democracy. https://doi.org/10.1177/0143831X17743794

Schunk, D. H. \& DiBenedetto, M. K. (2016). Self-efficacy theory in education. I K. R. Wentzel \& D. B. Miele (Red.), Handbook of motivation at school (s. 34-54). Routledge.

Skaalvik, E. M. \& Skaalvik, S. (2013). Skolen som læringsarena: Selvoppfatning, motivasjon og læring (2. utgave). Universitetsforlaget.

Solem, A., Buvik, M. P., Finnestrand, H. O., Landmark, A., Magerøy, K. \& Ravn, J. E. (2016). Fagarbeiderkompetanse: Kartlegging av dagens og fremtidens kompetansebehov i fagarbeiderrollen, $i$ industri og bygg og anlegg (SINTEF-rapport A27716). SINTEF. http:/ / hdl.handle.net/11250/2563296

Vallerand, R. J., Blais, M. R., Brière, N. M., Senécal, C. \& Vallières, E. F. (1997). Self-determination and persistence in a real-life setting: Toward a motivational model of high school dropout. Journal of Personality and Social Psychology, 72(5), 1161-1176.

White, R. W. (1959). Motivation reconsidered: The concept of competence. Psychological Review, 66(5), 297-333.

Øyum, L., Olsen, D. S. \& Thøring, L. (2019). From terrible teen to terrific trainee: Norwegian cases of innovative workplace-school collaboration to educate young people to become skilled workers in modern manufacturing industry. European Journal of Workplace Innovation, 4(2), 232-250. 